\title{
Literature Review: Gizi Antenatal terhadap Kejadian Stunting
}

\section{Literature Review: Antenatal Nutrition with Stunting}

\author{
Terry Y.R. Pristya ${ }^{1}$, Azizah Musliha Fitri ${ }^{2}$, Widyani Wahyuningtyas ${ }^{3}$ \\ Fakultas Ilmu Kesehatan, Universitas Pembangunan Nasional Veteran Jakarta, Indonesia
}

\section{ARTICLE INFO}

\section{Article history}

Received date

14 Jun 2021

Revised date

18 Jun 2021

Accepted date

03 Aug 2021

\section{Keywords:}

Antenatal;

Nutrition;

Pregnancy;

Stunting.

\section{Kata kunci:}

Antenatal;

Gizi;

Kehamilan;

Stunting.

\author{
ABSTRACT/ ABSTRAK
}

The period of pregnancy is one of the two causes of stunting. Nutritional intake during pregnancy is necessary for the growth and development of the organs that are being formed. The purpose of this literature review is to analyze the factors that cause stunting originating from pregnancy in terms of antenatal nutrition. This study is a literature review which is a primary data research article on antenatal nutrition on stunting conducted in Indonesia. The data source used is in the form of journal publications with research locations in Indonesia. Search for articles using a search engine with databases on Google Scholar and Garuda Portal. Keywords in English and Indonesian, include nutrition, pregnant women, stunting, nutrition, antenatal, pregnancy. Obtained 5 articles that fit the inclusion criteria then synthesized the data. The results showed that the factors causing stunting originating from the period of pregnancy in terms of antenatal nutrition consisted of protein, energy, and iron. One of the actions that can be taken to avoid deficiency of these nutritional elements during pregnancy is by providing education to pregnant women to pay attention to nutritional intake during pregnancy.

\begin{abstract}
Masa kehamilan merupakan satu dari dua masa penyebab terjadinya stunting. Asupan gizi selama kehamilan diperlukan untuk pertumbuhan dan perkembangan organ yang sedang terbentuk. Tujuan dari kajian tinjuan literatur ini adalah untuk menganalisa faktor penyebab stunting yang berasal dari masa kehamilan dilihat dari segi gizi antenatalnya. Penelitian ini merupakan kajian literatur yang merupakan artikel penelitian data primer tentang gizi antenatal terhadap stunting yang dilakukan di Indonesia. Sumber data yang digunakan berupa publikasi jurnal dengan lokasi penelitian di wilayah Indonesia. Penelusuran artikel menggunakan mesin pencarian yang database di Google Scholar dan Portal Garuda. Kata kunci dalam bahasa inggris maupun bahasa indonesia, meliputi: gizi, ibu hamil, stunting, nutrition, antenatal, pregnancy. Didapatkan 5 artikel yang sesuai kriteria inklusi kemudian dilakukan sintesis data. Hasil penelitian menunjukkan bahwa faktor penyebab stunting yang berasal dari masa kehamilan dilihat dari segi gizi antenatalnya terdiri dari protein, energi, dan zat besi. Salah satu tindakan yang dapat dilakukan untuk menghindari kekurangan unsur gizi tersebut selama masa kehamilan adalah dengan melakukan pemberian edukasi kepada ibu-ibu hamil agar memperhatikan asupan gizi makanan selama hamil.
\end{abstract}

Corresponding Author:

Terry Y.R. Pristya

Fakultas Ilmu Kesehatan, Universitas Pembangunan Nasional Veteran Jakarta, Indonesia

Email: terry.yuliana@gmail.com

\section{PENDAHULUAN}

Secara global, prevalensi stunting antara tahun 2000 hingga 2019 mengalami penurunan dari $32,4 \%$ menjadi $21,3 \%$. Anak-anak yang terdampak stunting menurun dari 199,5 juta menjadi 144 juta anak. Asia Selatan menjadi daerah dengan prevalensi stunting tertinggi di dunia yaitu sebesar 33,2\% (UNICEF, 2020).

Di Indonesia sendiri menjadi salah satu negara dengan triple burden permasalahan gizi yang meliputi stunting, wasting, dan overweight (Kemenkes RI, 2019). Gambaran dari salah satu triple burden tersebut digambarkan dalam hasil 
Riskesdas 2018 yang menujukkan bahwa sebanyak $30,8 \%$ balita memiliki tinggi badan yang tidak sesuai dengan usianya atau stunting (Balitbangkes, 2018). Sementara pada Riskesdas 2013, angkanya lebih tinggi hingga mencapai $37 \%$ balita yang mengalami stunting (Balitbangkes, 2014). Artinya, angka stunting di Indonesia mengalami penurunan. Namun, Badan Kesehatan Dunia menyatakan bahwa ambang batas masalah kesehatan masyarakat suatu negara dinyatakan sangat tinggi apabila terdapat $\geq 30 \%$ kasus balita stunting (De Onis, et al., 2019). Oleh karena itu, stunting masih menjadi permasalahan gizi prioritas di Indonesia, walaupun angkanya menurun dalam lima tahun tersebut.

Stunting merupakan salah satu hambatan yang paling signifikan bagi perkembangan manusia (WHO, 2014). Kondisi anak yang stunting mengalami gangguan tumbuh kembang akibat dari gizi buruk, infeksi yang berulang, serta stimulasi psikososial yang tidak memadai. Gangguan tumbuh kembang tersebut dimulai pada awal kehidupan, yaitu pada seribu hari pertama kehidupan atau 1000 HPK (WHO, 2015). Seribu hari tersebut dimulai dari masa awal kehidupan yaitu 270 hari (9 bulan) masa kehamilan hingga 730 hari hingga usia 2 tahun. Masa tersebut sangat penting dan menjadi periode emas bagi anak untuk tumbuh serta berkembang secara normal (Achadi, Achadi, \& Aninditha, 2020).

Apabila mengalami gangguan pada masa emas tersebut, maka akan terjadi konsekuensi fungsional yang merugikan anak. Beberapa konsekuensi tersebut meliputi kognisi dan kinerja pendidikan yang buruk, hilangnya produktivitas, serta peningkatan risiko penyakit kronis terkait nutrisi pada saat dewasa (WHO, 2015).

Interaksi antara kekurangan gizi dan infeksi dapat menciptakan siklus yang berpotensi pada kematian yang berasal dari kondisi penyakit dan status gizi yang memburuk (UNICEF, 2020). Penyebab stunting dibagi menjadi dua masa, yaitu saat dalam kandungan dan pasca anak tersebut lahir. Pertumbuhan dan perkembangan dalam kandungan sangat penting karena semua organ tubuh dibentuk, tumbuh, serta berkembang. Salah satu indikator adanya gangguan pertumbuhan dalam kandungan adalah panjang badan lahir yang rendah. Artinya, apabila seorang anak sejak masa kandungan mengalami masalah terutama kekurangan gizi, maka salah satunya akan berakibat pada tubuh yang pendek atau stunting (Achadi, et al., 2020).

Gizi antenatal dibagi menjadi dua, yaitu: makronutrien dan mikronutrien. Pada makronutrien meliputi energi, protein, glikemik, dan lemak. Sedangkan untuk mikronutrien meliputi: folat, vitamin, kalsium, iodin, besi, seng, dan alkohol/kafein (Mousa, Naqash, \& Lim, 2019). Status gizi antenatal atau selama masa kehamilan dan kondisi ibu selama hamil menjadi salah satu faktor penyebab stunting pada balita. Kedua penyebab tersebut merupakan faktor risiko terhambatnya pertumbuhan dalam masa kandungan. Faktor risiko stunting yang berasal dari status gizi antenatal meliputi: kurangnya energi kronis (KEK), anemia, protein, pertumbuhan berat badan selama hamil, ibu hamil pendek, paparan nikotin dan asap rokok, kehamilan saat usia muda, dan status gizi ibu hamil itu sendiri (Achadi, et al., 2020; Ernawati, Rosmalina, \& Permanasari, 2013).

Tujuan dari kajian tinjauan literatur ini adalah untuk menganalisa faktor penyebab stunting dilihat dari gizi antenatalnya. Dengan adanya kajian literatur ini diharapkan dapat memberikan gambaran gizi antenatal yang berhubungan dengan kejadian stunting, sehingga dapat memberikan upaya pencegahan terjadinya stunting sejak awal kehamilan.

Penelitian ini merupakan sebuah literature review. Artikel yang digunakan merupakan penelitian-penelitian data primer yang relevan tentang gizi antenatal terhadap stunting dan dilakukan di Indonesia. Strategi pencarian artikel yang digunakan menggunakan kriteria inklusi sebagai berikut:

1. Artikel penelitian dengan menggunakan desain penelitian longitudinal, kasus kontrol, maupun cross-sectional.

2. Gizi yang masuk ke dalam kriteria inklusi merupakan gizi pada ibu hamil, bukan gizi pada balitanya. Untuk penelitian dengan gizi pada balita tidak diikutsertakan dalam penelitian.

3. Naskah yang dipublikasi menggunakan Bahasa Inggris atau Bahasa Indonesia.

4. Batasan pencarian artikel merupakan artikel yang dipublikasi mulai tahun 2010 hingga 2020.

5. Hanya artikel yang dapat diunduh secara gratis yang digunakan dalam penelitian ini.

Sumber data yang digunakan berupa publikasi jurnal dengan lokasi penelitian di wilayah Indonesia. Metode strategi pencarian menggunakan PRISMA (Preferred Reporting Items for Systematic Review \& Meta Analysis) melalui empat tahapan yang terdiri dari identification, screening, eigibility, dan terakhir included. Penelusuran artikel menggunakan mesin pencarian yang database di Google Scholar dan Portal Garuda. Dalam strategi pencariannya, seleksi dokumen menggunakan 
beberapa kata kunci yaitu: "gizi”, "ibu hamil", "stunting", "nutrition", "antenatal", dan "pregnancy" pada database tersebut.

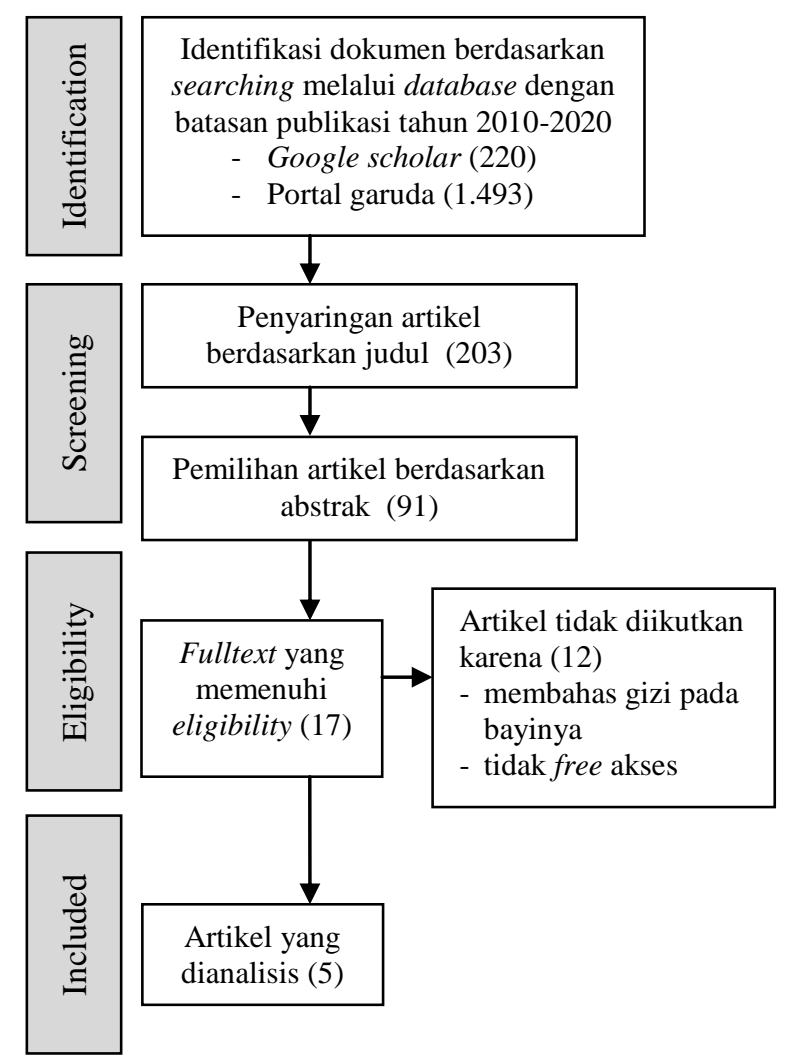

\section{Gambar 1. Alur Pencarian Artikel}

Berdasarkan hasil penelusuran menggunakan kata kunci melalui mesin pencarian, pada tahap pertama flowchart PRISMA yaitu identification melalui proses seleksi artikel dilakukan dengan mengidentifikasi dokumen melalui dua database yaitu Google Scholar didapatkan sebanyak 220 artikel dan Portal Garuda didapatkan sebanyak 1.493 artikel. Seluruh artikel yang tersaring tersebut merupakan publikasi pada sepuluh tahun terakhir saja.

Tahap kedua dengan melakukan screening. Dari artikel yang telah tersaring, kemudian dilakukan eliminasi berdasarkan judul dan didapatkan sebanyak 203 artikel dengan judul yang relevan dengan literature review ini. Eliminasi kedua dilakukan kembali berdasarkan abstrak, sehingga hanya didapatkan 91 artikel.

Pada tahap ketiga yaitu eligibility dengan melakukan proses seleksi artikel diperketat dengan melakukan pemilihan artikel yang tersedia full text nya saja. Dari artikel full text tersebut dipilih kembali yang memenuhi eligibility penelitian dan tidak mengikutsertakan pada artikel yang membahas gizi pada balita, serta artikel yang berbayar atau tidak free akses. Hanya 17 artikel terpilih yang memenuhi eligibility penelitian. Jumlah artikel yang tidak diikutkan dalam analisis penelitian ini sebanyak 12 artikel. Sehingga, pada tahap terakhir included dari total artikel yang disaring berdasarkan kriteria inklusi tersebut, diperoleh sebanyak 5 artikel dengan naskah yang sesuai. Kemudian kelima naskah tersebut dilakukan sintesis data untuk memperoleh penyebab stunting yang berasal dari gizi antenatal (Gambar 1).

\section{PEMBAHASAN}

Penelusuran artikel yang telah dilakukan menggunakan flowchart PRISMA berdasarkan kriteria inklusi penelitian seperti naskah yang diikutkan hanya yang membahas gizi pada ibu hamil, serta tidak berbayar didapatkan hasil sebanyak 5 artikel yang masuk ke dalam kriteria (Tabel 1). Kelima artikel merupakan penelitian yang dilakukan lima wilayah Indonesia berbeda yaitu: Bogor, Lampung Selatan, Madiun, Maros, dan Lampung Tengah. Walaupun batasan publikasi yang dimasukkan dalam kriteria inklusi mulai tahun 2010 hingga 2020, tetapi artikel yang didapatkan dalam penelitian ini hanya terdiri dari tahun 2013, 2018, 2019, dan 2020. Jenis desain studi penelitian yang digunakan pada artikel meliputi satu penelitian menggunakan desain studi longitudinal, dua penelitian menggunakan desain studi kasus kontrol, dan dua penelitian menggunakan desain studi potong lintang. Sedangkan analisis data yang digunakan pada kelima artikel tersebut mayoritas menggunakan analisis chi-square, dan hanya satu artikel yang dianalisis menggunakan regresi cox. Jumlah sampel pada artikel beragam. Paling sedikit merupakan penelitian di Madiun dengan jumlah responden 82 orang, sedangkan paling banyak penelitian di Bogor dengan responden hingga 262 orang.

Hasil penelitian longitudinal di Bogor pada 262 ibu hamil dengan usia kehamilan 12-16 minggu yang diikuti hingga anak berusia 12 bulan, menunjukkan bahwa asupan protein pada ibu hamil berpengaruh terhadap kejadian stunting. Hasil analisis regresi cox diperoleh bahwa ibu yang kehamilannya pada trimester kedua mengonsumsi protein kurang dari rata-rata ( $<58 \%$ AKG), memiliki risiko 1,6 kali untuk melahirkan bayi stunting pada usia 12 bulan dibandingkan ibu yang kehamilannya pada trimester kedua mengonsumsi protein lebih dari rata-rata ( $\geq 58 \% \mathrm{AKG}$ ) (Ernawati, et al., 2013).

Penelitian kasus kontrol di Lampung Selatan menggunakan uji chi-square pada 104 sampel ibuibu yang memiliki balita usia 24-59 bulan 
menunjukkan bahwa ibu yang selama kehamilannya mengalami kekurangan energi kronis (KEK) menjadi faktor risiko kejadian stunting pada balita (usia 24-59 tahun) (Nubli, 2020).

Penelitian kasus kontrol lainnya pada 82 balita yang terdiri dari 27 balita kasus dan 55 balita kontrol di Madiun menunjukkan bahwa adanya hubungan yang signifikan antara riwayat anemia kehamilan dengan kejadian stunting ( $p$-value $0,005)$. Analisis lanjutan pada penelitian tersebut menunjukkan bahwa ibu yang memiliki riwayat kekurangan besi selama kehamilannya, memiliki risiko 4 kali lebih tinggi bayinya untuk mengalami stunting dibandingkan ibu yang tidak memiliki riwayat kekuranga besi selama kehamilannya (Widyaningrum \& Romadhoni, 2018).

Sukmawati, et al. (2018) melakukan penelitian potong lintang terhadap 95 sampel balita yang dipilih secara simple random sampling di
Wilayah Kerja Puskesmas Bontoa Kabupaten Maros. Hasil analisis chi-square menunjukkan bahwa status gizi ibu saat hamil dilihat dari LILA (KEK atau tidak) berhubungan secara statistik dengan kejadian stunting ( $p$-value 0,01 ).

Hasil penelitian potong lintang di Lampung Tengah pada 237 ibu-ibu yang memiliki balita yang dipilih dengan cara purposive sampling menyatakan bahwa terdapat hubungan yang bermakna antara status gizi ibu selama kehamilan terhadap kejadian stunting pada balita usia 6-59 bulan. Analisis lanjutan diperoleh bahwa ibu yang selama kehamilannya mengalami KEK memiliki risiko 2,2 kali lebih besar untuk balitanya stunting dibandngkan dengan ibu yang selama kehamilannya tidak mengalami KEK (Alfarisi, Nurmalasari, \& Nabilla, 2019).

Tabel 1. Gizi Antenatal terhadap Stunting

\begin{tabular}{|c|c|c|c|c|c|c|c|}
\hline No & Peneliti & $\begin{array}{c}\text { Desain } \\
\text { studi }\end{array}$ & $\begin{array}{c}\text { Jenis } \\
\text { Analisis }\end{array}$ & Sampel & Tempat & Gizi & Temuan \\
\hline 1 & $\begin{array}{l}\text { Ernawati, } \\
\text { et al. } \\
(2013)\end{array}$ & $\begin{array}{l}\text { Longi- } \\
\text { tudinal }\end{array}$ & $\begin{array}{l}\text { Regresi } \\
\text { cox }\end{array}$ & $\begin{array}{l}262 \mathrm{ibu} \\
\text { hamil }\end{array}$ & Bogor & Protein & $\begin{array}{l}\text { Ibu yang mengkonsumsi } \\
\text { protein kurang dari rata- } \\
\text { rata }(<58 \% \text { AKG) pada } \\
\text { trimester kedua } \\
\text { mempunyai risiko } 1,6 \text { kali } \\
\text { mengalami stunting }\end{array}$ \\
\hline 2 & $\begin{array}{l}\text { Nubli, } \\
\text { (2020) }\end{array}$ & $\begin{array}{l}\text { Kasus } \\
\text { kontrol }\end{array}$ & $\begin{array}{l}\text { Chi- } \\
\text { square }\end{array}$ & $\begin{array}{l}104 \mathrm{ibu} \\
\text { yang } \\
\text { memiliki } \\
\text { balita usia } \\
24-59 \text { bulan }\end{array}$ & $\begin{array}{l}\text { Lampung } \\
\text { Selatan }\end{array}$ & Energi & $\begin{array}{l}\text { Kekurangan Energi Kronis } \\
\text { (KEK) ibu hamil sebagai } \\
\text { faktor risiko kejadian } \\
\text { stunting pada balita (usia } \\
24-59 \text { tahun) }\end{array}$ \\
\hline 3 & $\begin{array}{l}\text { Widya } \\
\text { Ningrum, } \\
\text { Romadhoni } \\
(2018)\end{array}$ & $\begin{array}{l}\text { Kasus } \\
\text { kontrol }\end{array}$ & $\begin{array}{l}\text { Chi- } \\
\text { square }\end{array}$ & $\begin{array}{l}82 \text { orang } \\
(27 \text { kasus } \\
\text { dan } 55 \\
\text { kontrol) }\end{array}$ & Madiun & Besi & $\begin{array}{l}\text { Ibu yang memiliki riwayat } \\
\text { kekurangan besi selama } \\
\text { kehamilannya, memiliki } \\
\text { risiko } 4 \text { kali lebih tinggi } \\
\text { bayinya untuk mengalami } \\
\text { stunting }\end{array}$ \\
\hline 4 & $\begin{array}{l}\text { Sukmawati, } \\
\text { et al. } \\
(2018)\end{array}$ & $\begin{array}{l}\text { Potong } \\
\text { lintang }\end{array}$ & $\begin{array}{l}\text { Chi- } \\
\text { square }\end{array}$ & 95 orang & Maros & Energi & $\begin{array}{l}\text { Status gizi ibu saat hamil } \\
\text { dilihat dari LILA (KEK } \\
\text { atau tidak) berhubungan } \\
\text { dengan kejadian stunting }\end{array}$ \\
\hline 5 & $\begin{array}{l}\text { Alfarisi, } \\
\text { et al. } \\
(2019)\end{array}$ & $\begin{array}{l}\text { Potong } \\
\text { lintang }\end{array}$ & $\begin{array}{l}\text { Chi- } \\
\text { square }\end{array}$ & $237 \mathrm{ibu}$ & $\begin{array}{l}\text { Lampung } \\
\text { Tengah }\end{array}$ & Energi & $\begin{array}{l}\text { Terdapat hubungan yang } \\
\text { bermakna antara status gizi } \\
\text { ibu selama kehamilan } \\
\text { terhadap kejadian stunting } \\
\text { pada balita usia 6-59 bulan }\end{array}$ \\
\hline
\end{tabular}

Secara umum, zat gizi yang diperlukan tubuh dalam semua daur kehidupan dibagi menjadi dua yaitu makronutrien dan mikronutrien. Pada zat gizi makro (makronutrien) terdiri dari karbohidrat, protein, dan lemak. Sedangkan pada zat gizi mikro (mikronutrien) terdiri dari vitamin dan mineral (Achadi, et al., 2020). Khusus pada ibu hamil, kebutuhan zat gizi tersebut memerlukan tambahan dalam jumlah yang lebih banyak. Tidak terpenuhinya kebutuhan zat gizi yang terakumulasi yang berlangsung lama hingga 24 bulan dapat menyebabkan terjadinya stunting pada anak (Mitra, 2015). Makronutrien dibutuhkan dalam jumlah yang cukup banyak dengan memberikan kalori atau energi dalam aktivitas sehari-hari untuk menjaga fungsi tubuh (WHO, 2020b). Selain unsur makronutrien tersebut, dalam masa 
kehamilan juga dibutuhkan adanya kecukupan energi (Mousa, et al., 2019).

Sedangkan mikronutrien hanya dibutuhkan dalam jumlah yang sangat kecil selama kehamilan, akan tetapi sangat penting dalam fungsi fisiologis, pertumbuhan, dan perkembangan normal. Macam-macam mikronutrien selama kehamilan meliputi zat besi, yodium, asam folat, seng, tembaga, kalsium, vitamin $\mathrm{A}$, vitamin $\mathrm{E}$, vitamin $\mathrm{B}$ (B1, B6, B12), vitamin $\mathrm{D}$, cholin, dan vitamin $\mathrm{C}$ (Achadi, et al., 2020). Seluruh zat gizi tersebut berfungsi dalam peningkatan kebutuhan nutrisi ibu, pertumbuhan, dan perkembangan otak janin. Akibat yang ditimbulkan apabila kekurangan gizi tersebut, maka akan berdampak pada kesehatan ibu maupun bayinya sepanjang hidupnya (WHO, 2020a). Oleh karenanya, penentuan kualitas manusia ditentukan sejak berada dalam masa kehamilan. Stunting merupakan indikator dari kekurangan gizi kronis, serta ketidakcukupan asupan makanan dalam waktu yang lama. Hal ini tidak menutup kemungkinan terjadi sejak dalam kandungan (Ernawati, et al., 2013).

Penilaian status gizi ibu hamil dapat diketahui melalui pengukuran lingkar lengan atas (LiLa). Pengukuran tersebut erat kaitannya dengan indeks masa tubuh ibu hamil, dimana semakin tinggi LiLa maka semakin tinggi indeks masa tubuhnya. Di negara berpenghasilan tinggi, gizi ibu hamil lebih difokuskan untuk menormalkan indeks masa tubuh, pemilihan pola makan yang sehat, serta evaluasi kekurangan zat gizi (Parisi, di Bartolo, Savasi, \& Cetin, 2019).

Berdasarkan kajian literatur melalui proses eliminasi artikel menggunakan metode PRISMA yang telah dilakukan, pada kelima artikel terpilih yang relevan dan memenuhi kriteria inklusi penelitian didapatkan beberapa unsur gizi antenatal yang diperlukan ibu hamil sebagai penyebab terjadinya stunting pada anak. Pada awal kehidupannya di seribu hari pertama kehidupan yaitu 270 hari dalam kandungan dan 730 hari pertama kehidupan, anak dengan kurang gizi kronis akan menjadi stunted di usia 2 tahun pertama. Gizi buruk maupun paparan patogen berkontribusi terhadap stunting (Achadi, et al., 2020).

\section{Protein}

Salah satu unsur mikronutrien gizi antenatal lainnya adalah protein. Sumber protein berasal dari sumber nabati seperti: kacang-kacangan, polongpolongan, dan biji-bijian, serta sumber hewani, seperti: daging dan susu (Mousa, et al., 2019). Asupan protein yang dianjurkan selama kehamilan adalah 60g/hari, meningkat dari 46g/hari saat sebelum hamil (Kominiarek \& Rajan, 2016).

Kurangnya asupan protein bagi ibu hamil menjadi faktor yang berisiko sangat signifikan terhadap terjadinya anak stunting saat usia 12 bulan, yaitu mencapai 1,6 kali dibandingkan ibu yang terpenuhi asupan proteinnya. Besarnya asupan protein yang berisiko tersebut rata-rata $<58 \%$ AKG pada trimester kedua kehamilan (Ernawati, et al., 2013). Rata-rata angka kecukupan protein yang dianjurkan untuk masyarakat Indonesia sebesar 57gram per orang per hari pada tingkat konsumsi. Sedangkan selama hamil pada trimester kedua untuk pemenuhan angka kecukupan gizi protein yang dianjurkan adanya penambahan sebanyak $+10 \mathrm{~g}$ protein (Permenkes, 2019).

Kualitas protein ditentukan oleh daya cerna dan kapasitasnya untuk memenuhi nitrogen serta kebutuhan asam amino yang sangat diperlukan untuk pertumbuhan, perbaikan dan pemeliharaan (Mousa, et al., 2019). Protein yang cukup diperlukan dalam proses pembelahan, pertumbuhan, serta perkembangan sel saraf. Apabila asupan protein pada ibu hamil di bawah 24 minggu kurang, maka akan menyebabkan jumlah sel berkurang. Sedangkan kekurangan asupan protein pada akhir kehamilan dapat menyebabkan ukuran sel saraf mengecil, dan jika terjadi kekurangan dalam jumlah yang besar maka dapat menurunkan berat otak anak hingga 25\% (Achadi, et al., 2020). Oleh karena itu, kekurangan protein selama kehamilan dapat memperbesar risiko stunting pada anak yang dilahirkan.

\section{Energi}

Energi merupakan faktor utama penentu gizi untuk pertambahan berat badan selama hamil meskipun kekurangan zat gizi lain yang dapat menghambat pertambahan berat badan (Aritonang, 2018). Rata-rata angka kecukupan energi bagi masyarakat Indonesia sebesar 2100 kilo kalori per orang per hari pada tingkat konsumsi (Permenkes, 2019). Sedangkan selama hamil, seorang ibu membutuhkan energi tambahan sekitar 10-15\% lebih banyak dibandingkan kebutuhan energi saat tidak hamil. Kekurangan energi kronis (KEK) dapat mengakibatkan tidak adekuatnya pertambahan berat badan selama hamil, sehingga kebutuhan gizi janin terhambat dan menjadi indikator penyebab stunting dari dalam kandungan (Achadi, et al., 2020).

Suplai energi saat hamil dilakukan dengan meningkatkan intik energi, mengurangi keluaran 
energi, serta meningkatkan efisiensi energi. Seluruh energi tersebut digunakan untuk mensintesis jaringan baru. Selama hamil, perubahan hormon dapat merubah penggunaan sumber energi yang menyebabkan energi untuk sintesis lemak atau protein menjadi berkurang. Sementara dalam pertumbuhannya, janin membutuhkan asam amino dan sumber glukosa. Hormon plasenta laktogen diproduksi oleh plasenta berperan dalam metabolik untuk promosi penggunaan lemak sebagai cadangan energi bagi ibu. Oleh karena itu, glukosa dan asam amino bagi jadi menjadi meningkat. Selama hamil akan terjadi peningkatan hormon chorionic somatomammotropin progesteron dan hormon kortisol untuk meningkatkan resistensi insulin peripheral ibu. Perubahan hormon tersebut akan meningkatkan simpanan energi setelah makan dan menggunakan cadangan energi ini dalam keadaan kurang makan (Aritonang, 2018).

Kenaikan berat badan selama kehamilan ditentukan dari asupan energi ibu hamil. Berbeda dengan sebelum hamil, energi yang diperlukan saat hamil lebih banyak karena adanya kebutuhan tambahan untuk janin yang sedang tumbuh dalam sintesis jaringan baru (plasenta, janin, dan cairan ketuban) serta pertumbuhan jaringan yang sudah ada (uterus, payudara, dan jaringan adiposa ibu). Oleh karena itu, makanan yang dimakan ibu harus memenuhi pasokan energi yag cukup (Mousa, et al., 2019).

Asupan energi meningkat selama masa kehamilan (Kominiarek \& Rajan, 2016). Tambahan energi tersebut berkisar 10-15\% lebih banyak dibandingkan sebelum hamil. Apabila tidak terpenuhi, maka ibu hami tersebut akan mengakibatkan kurang energi kronis (KEK) yang ditandai dengan indeks masa tubuhnya (IMT) $<18,5$ dan nilai lingkar lengan atas (LiLa) $<23,5$ $\mathrm{cm}$ (Achadi, et al., 2020). Energi yang dibutuhkan selama hamil tersebut digunakan untuk pertumbuhan serta pemeliharaan janin, plasenta, dan jaringan ibu (Aritonang, 2018). Sama halnya dengan protein, energi yang cukup juga diperlukan dalam proses pembelahan, pertumbuhan, serta perkembangan sel saraf. Apabila asupan energi pada ibu hamil di bawah 24 minggu kurang, maka akan menyebabkan jumlah sel berkurang. Sedangkan kekurangan asupan energi pada akhir kehamilan dapat menyebabkan ukuran sel saraf mengecil, dan jika terjadi kekurangan dalam jumlah yang besar maka dapat menurunkan berat otak anak hingga $25 \%$. Ibu hamil yang mengalami KEK mengakibatkan tidak mampu dalam memenuhi kebutuhan zat gizi yang dibutuhkan janin untuk tumbuh dan berkembang. Akibatnya menjadi risiko penyebab stunting dalam masa kandungan (Achadi, et al., 2020). Oleh karena itu, kekurangan asupan energi kronis selama kehamilan dapat memperbesar risiko stunting pada anak yang dilahirkan.

Pada hasil penelitian Sukmawati, et al. (2018), Alfarizi (2019), dan Nubli (2020) disimpulkan bahwa bahwa gizi ibu sebelum hamil dilihat dari status ibu kekurangan energi kronik atau tidak yang dilihat dari ukuran LiLa berhubungan dan menjadi faktor risiko dengan kejadian stunting pada anak.

\section{Zat Besi}

Zat besi merupakan salah satu gizi mikronutrien yang diperlukan ibu hamil. Kekurangan zat gizi besi atau anemia merupakan suatu kondisi dimana jumlah sel darah merah atau hemoglobin berada di bawah normal. Menurut data WHO, sebanyak 40\% ibu hamil di dunia yang mengalami anemia. Anemia menjadi permasalahan kesehatan masyarakat global tidak hanya bagi ibu hamil akan tetapi bagi anak-anak di dunia (WHO, 2017).

Selama masa kehamilan, kebutuhan zat besi dua kali lebih banyak dibandingkan saat sebelum hamil. Hal ini dikarenakan kebutuhan feto plasenta dan ibu yang lebih banyak yang terserap dari trimester awal hingga akhir (Parisi, et al., 2019). Batas normal kadar hemoglobin saat hamil sebesar 12,1-15,1g/dL. Pada trimester awal, ibu hamil dikatakan anemia jika kadar hemoglobinnya $<11 \mathrm{~g} / \mathrm{dL}$, trimester kedua $<10,5 \mathrm{~g} / \mathrm{dL}$, sedangkan trimester ketiga $<11 \mathrm{~g} / \mathrm{dL}$ (Kominiarek \& Rajan, 2016).

Ibu yang memiliki riwayat kekurangan besi selama kehamilannya, maka anaknya memiliki risiko 4 kali lebih tinggi untuk mengalami stunting dibandingkan dengan ibu yang tidak memiliki riwayat kekurangan besi selama kehamilannya (Widyaningrum \& Romadhoni, 2018).

Defisiensi zat besi menjadi salah satu penyebab terjadinya anemia, dimana kondisi sel darah merah atau hemoglobin jumlahnya kurang dari normal yang fungsinya untuk membawa oksigen ke seluruh jaringan tubuh. Bagi ibu, dampaknya seperti lemah, letih, dan nafas pendek. Plasenta menjadi tidak berkembang dengan sempurna yang berdampak pada gangguan abnormalitas struktur plasenta dan berat yang lebih rendah. Hal ini mengakibatkan janin mengalami hambatan pertumbuhan dan perkembangan selama dalam kandungan. Ibu hamil yang mengalami anemia berisiko terhadap terhambatnya pertumbuhan janin/PJT/IUGR, prematur, BBLR, dan simpanan Fe yang rendah 
pada bayi yang dilahirkan sehingga berisiko mengalami anemia pada usia 6 bulan (Achadi, et al., 2020). Oleh karena itu, ibu hamil yang mengalami anemia meningkatkan risiko untuk melahirkan anak dengan panjang lahir pendek atau stunting (Widyaningrum \& Romadhoni, 2018).

Gizi antenatal lainnya baik makronutrien maupun mikronutrien pada kajian literatur ini tidak menjadi faktor risiko terjadinya stunting. Unsur tersebut meliputi: lemak, vitamin, mineral, asam folat, yodium, kalsium, dan omega. Namun, unsur-unsur tersebut secara langsung menjadi penyebab stunting pasca lahir. Kurang beragamnya jenis makanan yang dimakan dalam MPASI menyebabkan terdapat zat gizi penting yang dibutuhkan namun tidak dipenuhi. Penyebab lainnya adalah tidak cukupnya jumlah makanan yang dikonsumsi, baik karena frekuensi makan yang rendah atau jumlah yang dimakan sedikit. Kebutuhan minimal akan zat gizi yang tidak terpenuhi dan berlangsung lama serta berulang dapat menyebabkan terjadinya stunting (Achadi, et al., 2020).

\section{DAFTAR PUSTAKA}

Achadi, E. L., Achadi, A., \& Aninditha, T. (2020). Pencegahan Stunting: Pentingnya Peran 1000 Hari Pertama Kehidupan. Jakarta: Rajagrafindo Persada.

Alfarisi, R., Nurmalasari, Y., \& Nabilla, S. (2019). Status Gizi Ibu Hamil dapat Menyebabkan Kejadian Stuting pada Balita. Jurnal Kebidanan Malahayati, 5(3), 271-278. https://doi.org/10.33024/jkm.v5i3.1404

Aritonang, E. Y. (2018). Kebutuhan Gizi Ibu Hamil. Bogor: IPB Press.

https://books.google.co.id/books?hl=en\&lr=\&id=L Rv7DwAAQBAJ\&oi=fnd\&pg=PP1\&dq=ke butuhan+gizi+manusia\&ots=bsifJN88td\&sig $=\mathrm{J} 9 \mathrm{rW} 1$ -

y43O8L9YS2xdosxUITS40\&redir_esc $=y \# v$ $=$ onepage $\& \mathrm{q}=$ kebutuhan gizi manusia\& $\mathrm{f}=$ false

Balitbangkes. (2014). Riskesdas 2013. Jakarta.

Balitbangkes. (2018). Hasil Utama Riset Kesehatan (RISKESDAS). Jakarta: Kementerian Kesehatan RI. https://doi.org/10.1088/17518113/44/8/085201

De Onis, M., Borghi, E., Arimond, M., Webb, P., Croft, T., Saha, K., ... Flores-Ayala, R. (2019). Prevalence thresholds for wasting, overweight and stunting in children under 5 years. Public Health Nutrition, 22(1),
Kurangnya asupan gizi antenatal dapat dicegah dengan melakukan dilakukan dengan melakukan pemberian pengetahuan kepada ibu hamil. Hal tersebut menjadi salah satu upaya pencegahan stunting, salah satunya dengan memperhatikan asupan gizi makanan yang masuk perlu dilakukan. Salah satunya dengan memberikan edukasi seperti yang dilakukan di Bogor. Bentuk pemberian edukasi melalui kelas ibu hamil yang terbukti efektif dalam meningkatkan pengetahuan ibu (Ekayanthi \& Suryani, 2019).

\section{SIMPULAN}

Faktor penyebab stunting yang berasal dari masa kehamilan dilihat dari segi gizi antenatalnya terdiri dari protein, energi, dan zat besi. Salah satu tindakan yang dapat dilakukan untuk menghindari kekurangan unsur gizi tersebut selama masa kehamilan adalah dengan melakukan pemberian edukasi kepada ibu-ibu hamil agar memperhatikan asupan gizi makanan selama hamil.

175-179.

https://doi.org/10.1017/S1368980018002434

Ekayanthi, N. W. D., \& Suryani, P. (2019).

Edukasi Gizi pada Ibu Hamil Mencegah

Stunting pada Kelas Ibu Hamil. Jurnal Kesehatan, 10(3), 312.

https://doi.org/10.26630/jk.v10i3.1389

Ernawati, F., Rosmalina, Y., \& Permanasari, Y. (2013). Pengaruh Asupan Protein Ibu Hamil dan Panjang Badan Bayi Lahir terhadap Kejadian Stunting pada Anak Usia 12 Bulan di Kabupaten Bogor. Nutrition and Food Research, 36(1), 1-11. https://doi.org/10.22435/PGM.V36I1.338. 1-11

Kemenkes RI. (2019). The Stategy and policy to involve property in Indonesia. Germas, 2(2), 41-52.

https://www.persi.or.id/images/2019/data/ FINAL_PAPARAN_PERSI_22_FEB_201 9_Ir._Doddy.pdf

Kominiarek, M. A., \& Rajan, P. (2016). Nutrition Recommendations in Pregnancy and Lactation. Medical Clinics of North America, 100(6), 1199-1215. https://doi.org/10.1016/j.mcna.2016.06.004

Mitra, M. (2015). Stunting Problems and Interventions to Prevent Stunting (A Literature Review). Jurnal Kesehatan 
Komunitas, 2(6 SE-), 254-261.

https://doi.org/10.25311/keskom.Vol2.Iss6.85

Mousa, A., Naqash, A., \& Lim, S. (2019). Macronutrient and micronutrient intake during pregnancy: An overview of recent evidence. $\quad$ Nutrients, $11(2)$. https://doi.org/10.3390/nu11020443

Nubli, M. A. (2020). Kurang Energi Kronis Ibu Hamil sebagai Faktor Risiko terhadap Kejadian Stunting pada Balita (usia 24-59 bulan) di Wilayah Kerja Puskesmas Way Urang Kecamatan Kalianda Lampung Selatan. [Skripsi]. Lampung: Fakultas Kedokteran Universitas Lampung. http://digilib.unila.ac.id/63089/

Parisi, F., di Bartolo, I., Savasi, V. M., \& Cetin, I. (2019). Micronutrient supplementation in pregnancy: Who, what and how much? Obstetric Medicine, 12(1), 5-13. https://doi.org/10.1177/1753495X18769213

Permenkes. (2019). Peraturan Menteri Kesehatan Republik Indonesia. Jakarta. http://hukor.kemkes.go.id/uploads/produk hukum/PMK_No_28_Th_2019_ttg_Angk a_Kecukupan_Gizi_Yang_Dianjurkan_Un tuk_Masyarakat_Indonesia.pdf

Sukmawati, S., Hendrayati, H., Chaerunnimah, C., \& Nurhumaira, N. (2018). Status Gizi Ibu Saat Hamil, Berat Badan Lahir Bayi Dengan Stunting Pada Balita Usia 06-36 Bulan Di Puskesmas Bontoa. Media Gizi
Pangan, 25(1), 18.

https://doi.org/10.32382/mgp.v25i1.55

UNICEF. (2020). Malnutrition in Children. https://data.unicef.org/topic/nutrition/maln utrition/

WHO. (2014). Global nutrition targets 2025: stunting policy brief.

https://www.who.int/publications/i/item/W HO-NMH-NHD-14.3

WHO. (2015). Stunting in a nutshell. https://www.who.int/nutrition/healthygrow thproj_stunted_videos/en/

WHO. (2017). Anaemia. https://www.who.int/healthtopics/anaemia\#tab=tab_1

WHO. (2020a). Multiple micronutrient supplementation during pregnancy. https://www.who.int/elena/titles/micronutri ents_pregnancy/en/

WHO. (2020b). WHO EMRO | Macronutrients | Health topics. http://www.emro.who.int/healthtopics/macronutrients/index.html

Widyaningrum, D. A., \& Romadhoni, D. A. (2018). Riwayat Anemia Kehamilan dengan Kejadian Stunting pada Balita di Desa Ketandan Dagangan Madiun. Medica Majapahit, $\quad$ 10(2), 86-99. http://ejournal.stikesmajapahit.ac.id/index. php/MM/article/view/291/271 